\title{
Effect of Treatment Temperature on the Initial Performance of Layers of Water-based Paints in Heat-treated Pine and Beech Wood
}

\author{
Mehmet Karamanoğlu, ${ }^{\mathrm{a}, *}$ Emre Birinci, ${ }^{\mathrm{b}}$ Haci İsmail Kesik, ${ }^{\mathrm{c}}$ and Alperen Kaymakc ${ }^{\mathrm{d}}$ \\ Hardness, surface roughness, and adhesion strength were determined for \\ water-based opaque paints applied to heat-treated wood material \\ surfaces. For this purpose, Scotch pine (Pinus sylvestris L.) and beech \\ (Fagus orientalis Lipsky) woods were used as experimental material. \\ Specimens were subjected to heat treatment at 3 different temperatures \\ $\left(150,180\right.$, and $\left.210^{\circ} \mathrm{C}\right)$ and 2 different periods ( 2 and $4 \mathrm{~h}$ ) under laboratory \\ conditions. Two-component water-based paints with commercial codes \\ D17 and D45 were applied to the surfaces. The hardness, surface \\ roughness, and adhesion strength values of painted samples were \\ determined according to the applicable standards. The results showed that \\ there were higher values of hardness and surface roughness of water- \\ based paints in short-term heat treatment compared with long-term heat \\ treatment. A general decrease in pine with D17 and D45 paints applied to \\ the surfaces and in beech with D45 in adhesion strength was detected \\ depending on the increasing heat treatment temperature and duration. An \\ increase was observed in beech samples with D17 paint applied.
}

DOI: 10.15376/biores.17.1.1494-1506

Keywords: Hardness; Surface roughness; Adhesion strength; Heat treatment; Water based paint

Contact information: a: Department of Materials and Materials Processing Technologies, Tosya Vocational School, Kastamonu University, Kastamonu, Turkey; b: Department of Forestry and Forest Products, Araç Rafet Vergili Vocational School, Kastamonu University, Kastamonu, Turkey;

c: Department of Wood Products Industrial Engineering, Faculty of Technology, Gazi University, Ankara, Turkey; d: Department of Forest Industry Engineering, Forestry Faculty, Kastamonu University, Kastamonu, Turkey; *Corresponding author: mkaramanoglu@ kastamonu.edu.tr

\section{INTRODUCTION}

Wood is preferred in many places of use due to its favorable properties and other advantages (Hill 2006; Kesik 2009; Kesik et al. 2015). Wood has excellent mechanical properties, although it is known to have some disadvantages such as its hygroscopicity and a tendency to undergo deformation and structural degradation when exposed to outdoor conditions or external effects; in addition, there are a lot of different processes to ameliorate these inadequacies (Kılıç and Hafızoğlu 2007; Karamanoğlu 2012; Kesik and Akyıldız 2015; Dagbro 2016; Karamanoğlu 2020). Heat treatment and protective layers (paint/ varnishes) are widely used to protect furniture and decoration materials produced with wood material (Sönmez et al. 2004; Cristea et al. 2010; Dunningham and Sargent 2015; Dagbro 2016).

Heat treatment is an environmentally friendly method to improve the properties of wood materials without the use of chemicals. After heat treatment, the dimensional stability of the wood material and its durability are greatly increased, if it is not directly in contact 
with the ground during its use (Dagbro et al. 2010; Demirel and Temiz 2015; Dagbro 2016).

Some properties of heat-treated wood material improve compared with non-heat treated (natural) material. However, when the wood material is exposed to the weathering (outdoor conditions or UV aging), the surface degradation continues, and the aesthetic appearance that the wood has gained with heat treatment is lost. For this reason, it is necessary to cover wood with protective layers to extend the life of natural and heat treated wood material and to protect its appearance (Militz 2002; Hill 2009; Miklečić et al. 2011; Miklečić et al. 2017).

Technological and application problems arise in solvent-based paints and thinners. Usage of such products also faces legal obligations imposed by the USA, European Community, and other developed countries on Volatile Organic Compounds (VOC) limits in paints and varnishes. Today there is an effort to overcome these problems with high solid content solvent-based paints, water-based paints, and electrostatic paints (Kimetsan 2021). Due to the low VOC values of water-based paints/varnishes, their production and consumption are increasing rapidly. At the same time, the variety in usage areas is increasing, and water-based finishes are widely used to protect wood material (Sönmez et al. 2004).

For the long-term performance of the protective paints layers, scientists and the paint industry attach importance to the adhesion of paints to the wood surface. For this reason, it is important to determine the adhesion strength by some methods such as tape peeling, observing the cross cut, and pull-off test (Bardage and Bjurman 1998; Dilik et al. 2015). Hardness is an important indicator of the resistance of paint and varnish layers to physical and mechanical effects (Kaygin and Akgün 2008). At the same time, the surface roughness of the wood plays an important role for the finishing process (Korkut et al. 2013). These parameters are affected in different ways by the changes in the polymers of the wood material, the equilibrium moisture content, and the density depending on the application temperature and duration of the heat treatment (Ünsal and Ayrılmış 2005; Akyıldız et al. 2009; Korkut and Budakçı 2010; Çakıcıer et al. 2011; Budakç1 et al. 2013; Kesik et al. 2014; Pelit 2014; Kesik and Akyıldız 2015; Gürleyen et al. 2017)

Hazır and Koç (2019) determined the highest adhesion resistance in water-based paints on MDF samples. Kabakc1 (2018) applied water-based thermal insulation paint to the surfaces of wood and wood-based parquets samples and determined its hardness and resistance to adhesion to the surface. Kesik et al. (2015) applied water-based varnish and paint on oil heat-treated Scotch pine (Pinus sylvestris L.) wood. They determined that the hardness of the varnish layers was higher than the paint layers and water-based varnish and that paint provide good adhesion to the heat-treated wood surface. Salca and Hizıroğlu (2014) studied evaluation of hardness and surface quality of different wood species as function of heat treatment. According to their results, hardness values of the specimens also decreased with increasing time and temperature treatments, which can be related to deterioration of the cell wall structure after the heat treatment.

There have been very limited studies on the layer performance of water-based opaque paints and the relationship between heat treatment and water-based paints. Therefore, this study determined the effect of heat treatment applied to Scotch pine (Pinus sylvestris L.) and beech (Fagus orientalis Lipsky) woods on the hardness, surface roughness, and adhesion strength of water-based paints. 


\section{EXPERIMENTAL}

\section{Wood Material}

Scotch pine (Pinus sylvestris L.) and beech (Fagus orientalis Lipsky) woods were obtained as kiln dried timber (thickness: 5 to $6 \mathrm{~cm}$, width: 14 to $15 \mathrm{~cm}$ and length: 300 to $320 \mathrm{~cm}$ ) from Kastamonu province, Turkey. Experimental materials were selected randomly from mixed core and sapwood, with smooth fibers, no knots, no cracks, no difference in color and density, and annual rings perpendicular to the surfaces according to ASTM D7787 / D7787M (2013).

\section{Paints}

Filling varnish (D18) and double-component opaque water-based paints (D17 and D45) were produced by Kimetsan Chemical, Mining and Metallurgical Industries International Trade Consulting \& Engineering Co. Ltd. (Ankara, Turkey). The paints were applied to the surface by mixing with improver at the level of $6 \%$ and with distilled water at the level of $6 \%$, prepared by weight, in accordance with the company directives. The technical and application properties of the varnish and paints are given in Table 1.

Table 1. Technical Properties for Varnish, Paints and their Application (Kimetsan)

\begin{tabular}{|l|c|c|c|c|c|c|}
\hline Layer Type & Content & $\mathrm{pH}$ & $\begin{array}{c}\text { Density } \\
\left(\mathrm{g} / \mathrm{cm}^{3}\right)\end{array}$ & $\begin{array}{c}\text { Viscosity } \\
(\mathrm{sn} . / \mathrm{DINCup} \\
\left.4 \mathrm{~mm} / 20^{\circ} \mathrm{C}\right)\end{array}$ & $\begin{array}{c}\text { Nozzle } \\
\text { Gap } \\
(\mathrm{mm})\end{array}$ & $\begin{array}{c}\text { Pressure } \\
(\text { Atü })\end{array}$ \\
\hline D18 filling & $\begin{array}{c}\text { Transparent - Nano Acrylic } \\
\text { Modified Polyurethane }\end{array}$ & 8.65 & 1.011 & 18 & 1 & 2 \\
\hline D17 paint & $\begin{array}{c}\text { Black pigmented - Nano } \\
\text { Acrylic Modified Polyurethane }\end{array}$ & 9.10 & 1.015 & 18 & 1 & 2 \\
\hline D45 paint & $\begin{array}{c}\text { Brown pigmented- Nano } \\
\text { Acrylic Modified Polyurethane }\end{array}$ & 8.20 & 1.022 & 18 & 1 & 2 \\
\hline
\end{tabular}

\section{Preparation of the Experimental Specimens}

Before the test samples were cut, the surfaces of the timbers were smoothed by planer (Netmak PL 500, Turkey) and thicknesser (Netmak KA 600 OTM, Turkey) machines. The direction of the fibers of the specimens used in the study was cut with a circular saw machine (MZK 2200 Prestij, Turkey) as a draft with the dimensions of $320 \mathrm{x}$ $105 \times 15 \mathrm{~mm}$ (length $\mathrm{x}$ width $\mathrm{x}$ thickness) parallel to the length axis, with the annual rings parallel to the two sides perpendicular to the other two sides and the intersecting faces perpendicular (ASTM D7787/ D7787M 2013). The samples were kept in the conditioning room with a temperature of $20 \pm 2{ }^{\circ} \mathrm{C}$ and a relative humidity of $65 \pm 5 \%$ until it reached a constant rate (TS 642 ISO 554 1997).

After conditioning, the samples were cut to $100 \times 100 \times 10 \mathrm{~mm}$ (700 pieces) in net dimensions with circular saw machine (MZK 2200 Prestij, Turkey). Later, some of the samples (100 pieces) were separated as a control group, and the others were subjected to heat treatment under atmospheric pressure in a laboratory-type oven at three different temperatures $\left(150,180\right.$, and $\left.210{ }^{\circ} \mathrm{C}\right)$ and two different times $(2$ and $4 \mathrm{~h})$. After the heat treatment, the test samples were left to condition again (TS 642 ISO 554 1997). To smooth the surfaces of the samples, clean them, and make the paints perfect, all samples were polished sequentially with 80 grit, 100 grit, and 220 grit sandpapers.

After cleaning the surfaces of the samples with a soft bristle brush and compressed air, they were prepared for painting. The painting of the samples was done with a Fuji 
Spray Q4 Gold machine (Toronto, ON, Canada) in accordance with the manufacturer's recommendations and ASTM D3023-98 (2017). The samples were painted with filling varnish ( 1 cross coat- 70 gr per $1 \mathrm{~m}^{2}$ ) and then lightly sanded with 600 grit sandpaper. The paints ( 2 cross coats -70 gr per $1 \mathrm{~m}^{2}$ ) were applied, with $24 \mathrm{~h}$ between the last layers in accordance with the company directives. The varnished samples were free from dust and dried in a room temperature environment parallel to the ground plane.

\section{Hardness Measurement}

The hardness values of the all samples were determined as Shore-D with Mitutoyo Hardmatic-HH-334 device (Neuss, Germany) according to ASTM D2240-15 (2021). Ten measurements were taken from each group.

\section{Surface Roughness Measurement}

The surface roughness measurements of the samples were made with the Accretech Handysurf E-35B needle scanning surface roughness measuring device (Tokyo Seimitsu, Munich, Germany) according to the principles of TS 6956 EN ISO 4287/A1 (2013). Roughness measurement was made perpendicular to the fibers. The average surface roughness $\left(R_{\mathrm{a}^{*}}\right)$ and ten-point average surface roughness $\left(R_{\mathrm{z}^{*}}\right)$ values of the samples were measured. Ten measurements were taken from each group. Measurements were made at room temperature, away from vibration and noise sources with a $5 \mu \mathrm{m}$ tip diameter, a 0.5 $\mathrm{mm} / \mathrm{sec}$ measuring speed, a $12.5 \mathrm{~mm}$ sampling length, and a $\lambda_{\mathrm{c}}=2.5 \mathrm{~mm}$ cut-off length. For measurement accuracy, the device was recalibrated every 50 measurements. The parallelism of the samples and the device to the ground plane checked and adjusted.

\section{Adhesion Strength Measurement}

The adhesion strength of varnishes to the surface was determined according to the principles of ASTM D4541 (2017). Measurements were made using a Shimadzu AG-IC $20 \mathrm{kN} / 50 \mathrm{kN}$ brand universal test device (Kyoto, Japan). Pull-off test cylinders with $20 \mathrm{~mm}$ diameter were attached to the sample surfaces with Bison two-component epoxy adhesive (without any solvent effect) at room temperature and with the help of special molds. The samples were left to dry for $24 \mathrm{~h}$. The layer on the surfaces to which the pull-off test cylinder is attached was cut along the material surfaces with the help of a cutter (Budakç1 2006). The samples were pulled from the cylinders attached to the surface in the universal tester, and the force at breaking was recorded. Five measurements were taken from each group. The test was completed within 90 seconds according to ASTM D4541 (2017). The adhesion strength was calculated as follows,

$$
X(\mathrm{MPa})=4 F / \pi \cdot d^{2}
$$

where $X$ is the adhesion strength (MPa), $F$ is the rapture force (Newton), and $d$ is the diameter of the test cylinders (mm) (Budakçı 2006).

\section{RESULTS AND DISCUSSION}

The values for the layer hardness, surface roughness, and adhesion strength values of D17 and D45 coded water-based paints applied to the surfaces of natural and heat-treated pine and beech wood are given in Table 2. The hardness values of D17 and D45 paints applied to the sample surfaces was higher in beech than in pine (Figs. 1 and 2). The 
penetration of water-based paints into wood, depending on the density, may have an effect on surface hardness (Sönmez et al. 2004; Budakç1 and Sönmez 2010; Ulay and Budakç1 2015; Can et al. 2021).

Table 2. Hardness, Surface Roughness, and Adhesion Strength Values of D17 and D45

\begin{tabular}{|c|c|c|c|c|c|c|c|c|c|c|}
\hline \multirow[b]{2}{*}{$\begin{array}{l}\text { Wood } \\
\text { Type }\end{array}$} & \multirow{2}{*}{$\begin{array}{c}\text { Heat } \\
\text { Treatment } \\
\text { Temperatures } \\
\left({ }^{\circ} \mathrm{C}\right) \\
\end{array}$} & \multirow[b]{2}{*}{$\begin{array}{l}\text { Time } \\
\text { Levels } \\
\text { (Hour) }\end{array}$} & \multicolumn{4}{|c|}{ D17 } & \multicolumn{4}{|c|}{ D45 } \\
\hline & & & $H$ & $R_{\mathrm{a}^{*}}$ & $R_{\mathrm{Z}^{*}}$ & AS & $H$ & $R_{\mathrm{a}^{*}}$ & $R_{\mathrm{Z}^{*}}$ & AS \\
\hline \multirow{7}{*}{ Pine } & Control & - & $\begin{array}{l}50.60 \\
(1.10)\end{array}$ & $\begin{array}{c}2.09 \\
(0.39)\end{array}$ & $\begin{array}{l}13.31 \\
(1.33)\end{array}$ & $\begin{array}{c}1.78 \\
(0.34)\end{array}$ & $\begin{array}{l}51.00 \\
(1.39)\end{array}$ & $\begin{array}{c}0.92 \\
(0.08)\end{array}$ & $\begin{array}{c}6.44 \\
(0.57)\end{array}$ & $\begin{array}{c}1.70 \\
(0.33)\end{array}$ \\
\hline & \multirow[b]{2}{*}{150} & 2 & $\begin{array}{l}51.20 \\
(1.51)\end{array}$ & $\begin{array}{c}1.64 \\
(0.21)\end{array}$ & $\begin{array}{l}11.69 \\
(1.00)\end{array}$ & $\begin{array}{c}1.70 \\
(0.61)\end{array}$ & $\begin{array}{l}51.70 \\
(1.18)\end{array}$ & $\begin{array}{c}0.93 \\
(0.07)\end{array}$ & $\begin{array}{c}6.34 \\
(0.86)\end{array}$ & $\begin{array}{r}1.99 \\
(0.33)\end{array}$ \\
\hline & & 4 & $\begin{array}{l}50.55 \\
(1.57)\end{array}$ & $\begin{array}{c}1.84 \\
(0.19)\end{array}$ & $\begin{array}{l}12.55 \\
(1.09)\end{array}$ & $\begin{array}{c}1.56 \\
(0.12)\end{array}$ & $\begin{array}{l}51.85 \\
(1.78)\end{array}$ & $\begin{array}{c}0.93 \\
(0.10)\end{array}$ & $\begin{array}{c}6.01 \\
(0.54)\end{array}$ & $\begin{array}{c}1.67 \\
(0.41)\end{array}$ \\
\hline & \multirow{2}{*}{180} & 2 & $\begin{array}{l}51.15 \\
(1.27)\end{array}$ & $\begin{array}{c}1.80 \\
(0.15)\end{array}$ & $\begin{array}{r}12.14 \\
(1.09)\end{array}$ & $\begin{array}{c}1.64 \\
(0.37) \\
\end{array}$ & $\begin{array}{l}52.00 \\
(1.63) \\
\end{array}$ & $\begin{array}{c}0.95 \\
(0.07) \\
\end{array}$ & $\begin{array}{c}6.36 \\
(0.97) \\
\end{array}$ & $\begin{array}{r}1.85 \\
(0.45) \\
\end{array}$ \\
\hline & & 4 & $\begin{array}{l}50.15 \\
(0.75)\end{array}$ & $\begin{array}{c}1.66 \\
(0.14)\end{array}$ & $\begin{array}{l}11.67 \\
(0.70)\end{array}$ & $\begin{array}{c}1.63 \\
(0.05)\end{array}$ & $\begin{array}{l}48.30 \\
(1.55)\end{array}$ & $\begin{array}{c}0.96 \\
(0.11)\end{array}$ & $\begin{array}{c}6.78 \\
(0.77)\end{array}$ & $\begin{array}{c}1.03 \\
(0.30) \\
\end{array}$ \\
\hline & \multirow{2}{*}{210} & 2 & $\begin{array}{l}51.65 \\
(1.33)\end{array}$ & $\begin{array}{c}1.00 \\
(0.08)\end{array}$ & $\begin{array}{c}7.24 \\
(0.56)\end{array}$ & $\begin{array}{c}1.49 \\
(0.36)\end{array}$ & $\begin{array}{l}51.65 \\
(1.33)\end{array}$ & $\begin{array}{c}1.00 \\
(0.08)\end{array}$ & $\begin{array}{c}7.24 \\
(0.56)\end{array}$ & $\begin{array}{c}1.49 \\
(0.36) \\
\end{array}$ \\
\hline & & 4 & $\begin{array}{l}45.45 \\
(1.92)\end{array}$ & $\begin{array}{c}2.01 \\
(0.27)\end{array}$ & $\begin{array}{r}13.14 \\
(1.40)\end{array}$ & $\begin{array}{c}0.92 \\
(0.26)\end{array}$ & $\begin{array}{l}46.90 \\
(1.60)\end{array}$ & $\begin{array}{c}1.05 \\
(0.15)\end{array}$ & $\begin{array}{c}6.34 \\
(0.83)\end{array}$ & $\begin{array}{c}1.15 \\
(0.12)\end{array}$ \\
\hline \multirow{7}{*}{ Beech } & Control & - & $\begin{array}{l}70.85 \\
(1.49)\end{array}$ & $\begin{array}{c}1.76 \\
(0.15)\end{array}$ & $\begin{array}{l}12.76 \\
(1.22)\end{array}$ & $\begin{array}{c}0.93 \\
(0.33)\end{array}$ & $\begin{array}{l}69.85 \\
(2.01)\end{array}$ & $\begin{array}{c}2.01 \\
(0.25)\end{array}$ & $\begin{array}{l}12.55 \\
(1.43)\end{array}$ & $\begin{array}{c}2.43 \\
(0.25)\end{array}$ \\
\hline & \multirow{2}{*}{130} & 2 & $\begin{array}{l}72.05 \\
(1.07)\end{array}$ & $\begin{array}{c}2.05 \\
(0.20)\end{array}$ & $\begin{array}{r}14.20 \\
(1.01)\end{array}$ & $\begin{array}{c}1.47 \\
(0.22)\end{array}$ & $\begin{array}{l}70.85 \\
(1.49) \\
\end{array}$ & $\begin{array}{c}1.99 \\
(0.13)\end{array}$ & $\begin{array}{c}12.71 \\
(1.21)\end{array}$ & $\begin{array}{c}2.34 \\
(0.22) \\
\end{array}$ \\
\hline & & 4 & $\begin{array}{l}70.15 \\
(0.97)\end{array}$ & $\begin{array}{c}1.95 \\
(0.16)\end{array}$ & $\begin{array}{l}13.37 \\
(0.83)\end{array}$ & $\begin{array}{c}2.52 \\
(0.23)\end{array}$ & $\begin{array}{l}70.35 \\
(0.71)\end{array}$ & $\begin{array}{c}1.75 \\
(0.22)\end{array}$ & $\begin{array}{l}11.89 \\
(1.56)\end{array}$ & $\begin{array}{c}2.26 \\
(0.46)\end{array}$ \\
\hline & \multirow{2}{*}{180} & 2 & $\begin{array}{l}71.65 \\
(1.06)\end{array}$ & $\begin{array}{c}1.65 \\
(0.08)\end{array}$ & $\begin{array}{l}11.67 \\
(0.66)\end{array}$ & $\begin{array}{c}2.74 \\
(0.33)\end{array}$ & $\begin{array}{l}71.30 \\
(1.25)\end{array}$ & $\begin{array}{c}1.51 \\
(0.23)\end{array}$ & $\begin{array}{l}10.72 \\
(2.20)\end{array}$ & $\begin{array}{c}2.20 \\
(0.26)\end{array}$ \\
\hline & & 4 & $\begin{array}{l}70.20 \\
(1.51)\end{array}$ & $\begin{array}{c}1.80 \\
(0.26)\end{array}$ & $\begin{array}{r}12.80 \\
(1.72)\end{array}$ & $\begin{array}{c}1.70 \\
(0.61)\end{array}$ & $\begin{array}{l}69.20 \\
(1.16)\end{array}$ & $\begin{array}{c}1.59 \\
(0.27)\end{array}$ & $\begin{array}{c}11.08 \\
(1.27)\end{array}$ & $\begin{array}{c}1.82 \\
(0.21)\end{array}$ \\
\hline & \multirow{2}{*}{210} & 2 & $\begin{array}{l}72.00 \\
(0.82)\end{array}$ & $\begin{array}{c}1.96 \\
(0.12)\end{array}$ & $\begin{array}{l}13.30 \\
(0.86)\end{array}$ & $\begin{array}{c}3.71 \\
(0.32)\end{array}$ & $\begin{array}{l}70.40 \\
(1.02)\end{array}$ & $\begin{array}{c}1.65 \\
(0.25)\end{array}$ & $\begin{array}{r}11.23 \\
(1.17)\end{array}$ & $\begin{array}{c}3.52 \\
(0.37)\end{array}$ \\
\hline & & 4 & $\begin{array}{l}67.30 \\
(0.71) \\
\end{array}$ & $\begin{array}{c}1.89 \\
(0.29)\end{array}$ & $\begin{array}{r}12.83 \\
(1.64)\end{array}$ & $\begin{array}{c}1.27 \\
(0.52)\end{array}$ & $\begin{array}{l}67.30 \\
(1.55)\end{array}$ & $\begin{array}{c}1.62 \\
(0.19)\end{array}$ & $\begin{array}{c}10.86 \\
(1.07)\end{array}$ & $\begin{array}{c}1.31 \\
(0.03)\end{array}$ \\
\hline
\end{tabular}

$H$ : Hardness, $R_{\mathrm{a}^{*}}$ : Average surface roughness, $R_{z^{*}}$ : Ten-point average surface roughness, AD: Adhesion Strength, ( ): Standard deviation.

Compared with control groups, the layer hardness of the D17 applied, heat treated pine samples generally increased in short-term heat treatment application and decreased in long-term heat treatment applications. In D45, an increase in the hardness with low temperature and duration of the heat treatment and a decrease in the hardness with high temperature and duration of the heat treatment were detected. Compared with controls, the layer hardness of both D17 and D45 applied beech increased in short-term applications at all heat treatment temperatures and decreased in long-term applications. In the literature, it was reported that while heat treatment increases the hardness of the protective layer in some cases, it decreases it in some cases (Kazan 2009; Çakıcıer et al. 2011; Pelit 2014; Gürleyen et al. 2017). Gürleyen et al. (2017) reported that in the heat treatment processes, the hardness increases initially and then decreases with the intensity of the heat treatment. 
They stated that hardness changes can vary depending on the type of wood, processing conditions, and even the direction of the tests. Pelit (2014) reported that the equilibrium moisture amount in the heat-treated wood material decreased with the increase in temperature, the surface hardness values of the wood material increased accordingly, and the high surface roughness in the high-temperature heat treatment affected the varnish layer hardness. At the same time, it was stated that the high surface roughness in high temperature heat treatment affects the hardness of the varnish layer.

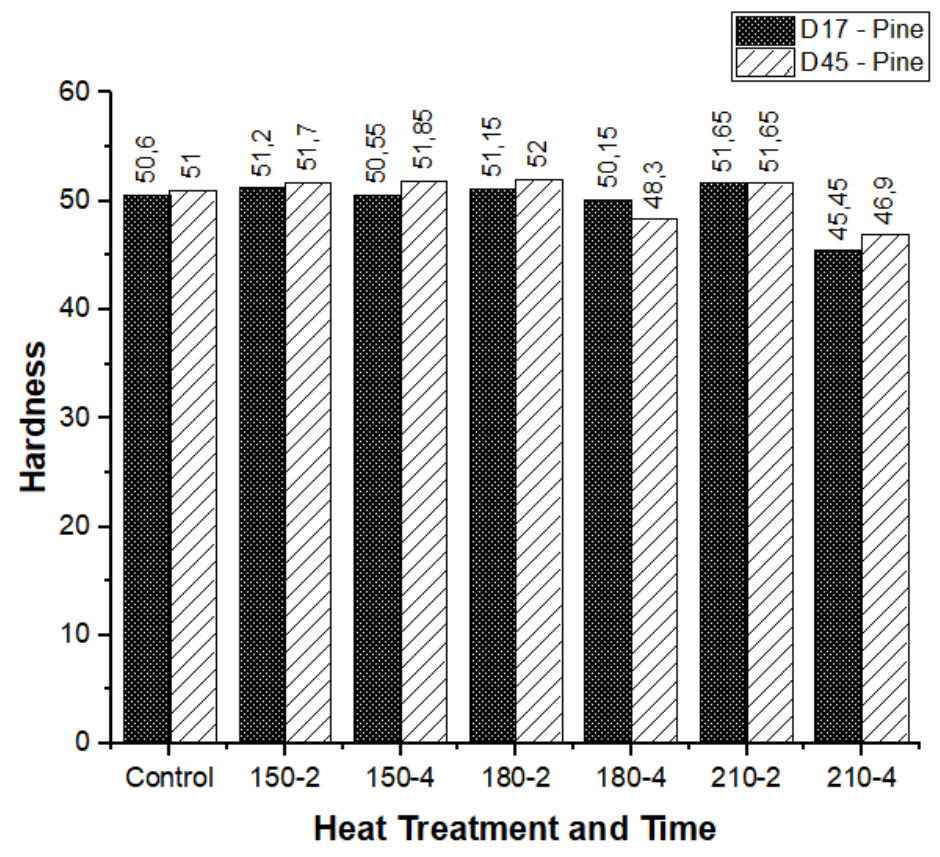

Fig. 1. D17 and D45 hardness in pine

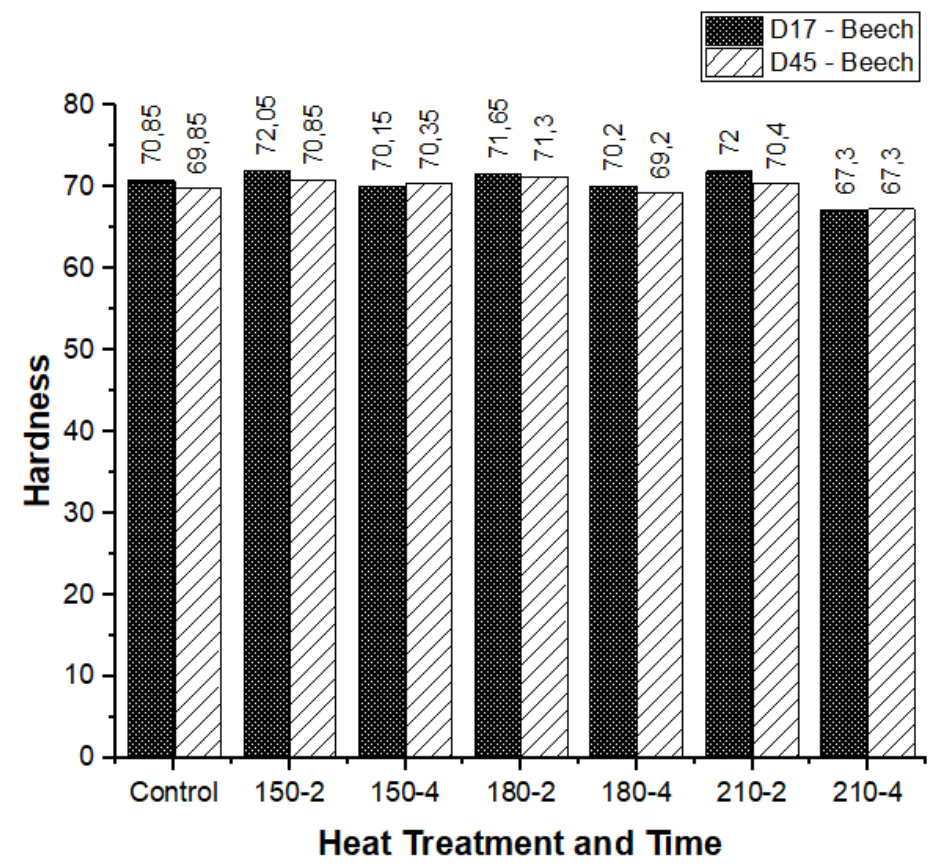

Fig. 2. D17 and D45 hardness in beech 
Except for $R_{\mathrm{a}^{*}}$ and $R_{\mathrm{Z}^{*}}$ beech control groups, the highest surface roughness values of the paints applied to the sample surfaces with and without heat treatment were determined in D17, both in pine and beech (Figs. 3 and 4). Compared with the control groups, $R_{\mathrm{a}} *$ and $R_{\mathrm{Z}^{*}}$ values decreased in the pine samples that were heat treated with D17 on their surfaces. The decreases in $R_{\mathrm{a}^{*}}$ and $R_{\mathrm{Z}^{*}}$ values were generally greater as the heat treatment temperature and duration increased. In D45, $R_{\mathrm{a}^{*}}$ increased due to the increasing heat treatment temperature and time, while $R_{\mathrm{Z}^{*}}$ decreased. Only $R_{\mathrm{Z}^{*}}$ increased after $4 \mathrm{~h}$ of heat treatment at $180{ }^{\circ} \mathrm{C}$ and $2 \mathrm{~h}$ of heat treatment at $210^{\circ} \mathrm{C}$ (Figs. 3 and 4 ).

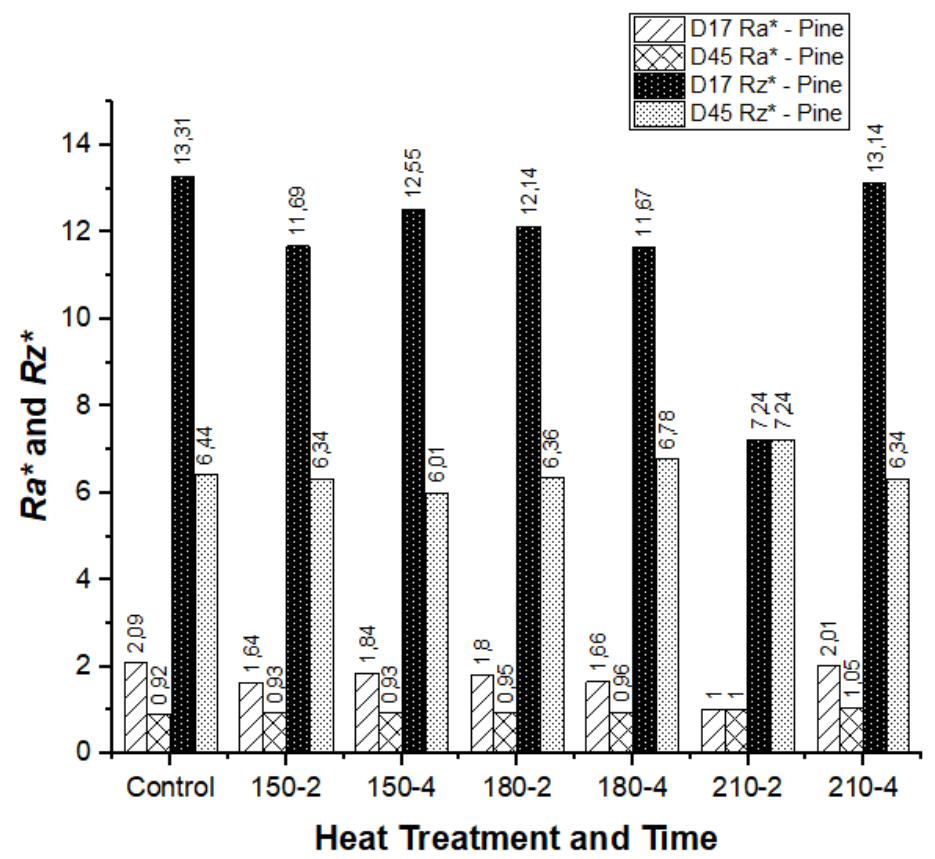

Fig. 3. D17 and D45 surface roughness in pine

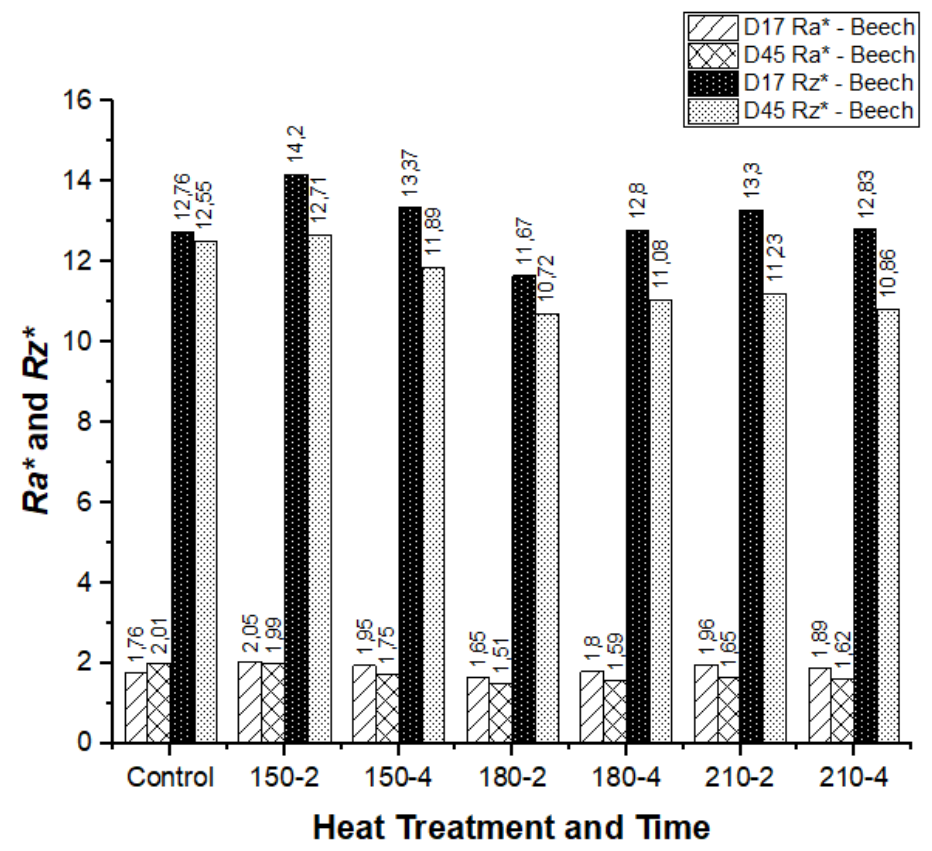

Fig. 4. D17 and D45 surface roughness in beech 
Compared with the control groups, $R_{\mathrm{a}^{*}}$ and $R_{\mathrm{Z}^{*}}$ increased at different rates with the effect of heat treatment temperature and time in the heat-treated beech samples on which D17 was applied. A decrease was detected in heat treatment for $2 \mathrm{~h}$ only at a temperature of $180{ }^{\circ} \mathrm{C}$. In $\mathrm{D} 45, R_{\mathrm{a}^{*}}$ and $R_{\mathrm{Z}^{*}}$ values decreased with the heat treatment. The highest decrease was observed in $2 \mathrm{~h}$ of heat treatment at $180{ }^{\circ} \mathrm{C}$. In this study, the surface roughness of the paints was affected differently. This result suggests a decrease in the density and surface roughness of the wood material with the effect of heat treatment and the paint structures.

In the literature, there are studies indicating that heat treatment decreases the density and surface roughness of wood material with increasing temperature and duration (Ünsal and Ayrılmış 2005; Korkut and Budakçı 2010; Budakçı et al. 2013; Kesik et al. 2014; Pelit 2014). Can (2020) reported that the reason for the decrease in surface roughness with heat treatment is the degradation of hemicellulose in the cell wall due to the applied high temperature. Pelit et al. (2015) reported that the surface roughness value increased depending on the increase in the heat treatment temperature. The grinding process applied to wood materials, which led to structural degradation and mass loss after heat treatment and before painting, affected the surface quality and increased the roughness. They determined that this situation leads to more deformation depending on the increase in the heat treatment temperature.

Depending on the increasing heat treatment temperature and time in the pine samples on which D17 was applied, the adhesion strength values of the paints applied to the heat-treated and non-heat-treated sample surfaces decreased when compared to the control groups. In D45, it increased in samples that were heat treated at 150 and $180{ }^{\circ} \mathrm{C}$ for $2 \mathrm{~h}$ and decreased in others (Figs. 5 and 6).

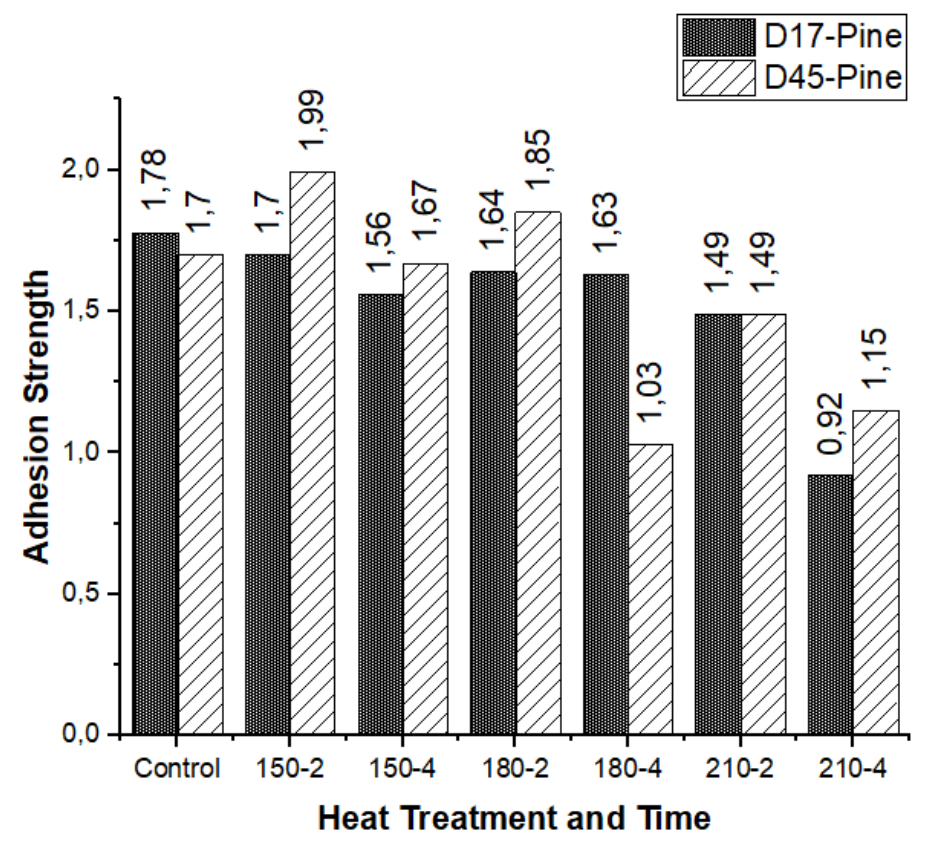

Fig. 5. D17 and D45 adhesion strength in pine 


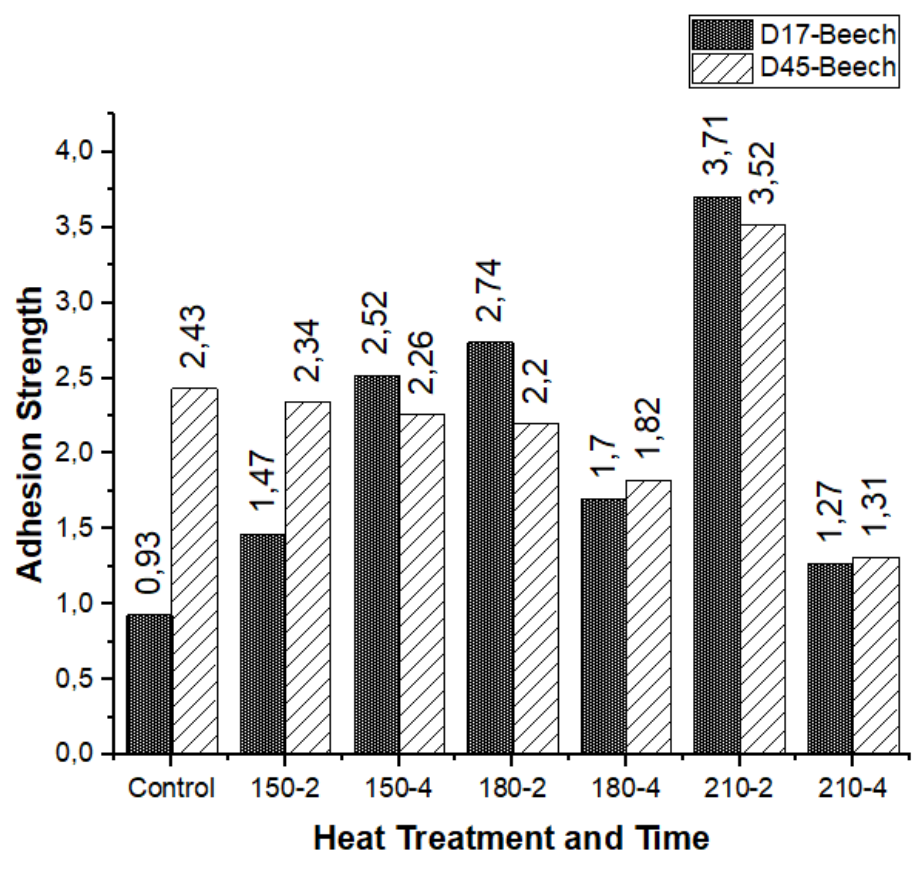

Fig. 6. D17 and D45 adhesion strength in beech

With the effect of heat treatment on the surface of D17 applied beech, the adhesion strength to the surface increased. The highest increase was determined in samples that were heat treated for $2 \mathrm{~h}$ at $210{ }^{\circ} \mathrm{C}$. In D45, the adhesion strength to the surface decreased with increasing heat treatment and temperature. It increased only in samples that were heat treated for $2 \mathrm{~h}$ at $210^{\circ} \mathrm{C}$. Heat treatment temperature and time are known to affect surface adhesion strength, and it brings out low values in varnishes. It has been stated that the mechanical properties of the wood material are adversely affected by the thermal decomposition that occurs after the heat treatment (Kesik and Aky1ldı 2015). Specially as a result of the depolymerization of wood polymers at temperatures above $100{ }^{\circ} \mathrm{C}$, intermolecular bonds are broken, ruptures increase depending on temperature, and adhesion bonds between varnish and wood material decrease. At the same time, increasing surface roughness, especially after temperatures above $180{ }^{\circ} \mathrm{C}$, causes low adhesion strength (Aydemir and Gündüz 2009; Pelit 2014; Kesik and Akyıldız 2015; Gürleyen et al. 2017; Altun and Esmer 2017).

Can et al. (2021) detected high adhesion strength at low temperatures and reported that heat treatment affects adhesion in three ways. (1) Heat treatment causes "case hardening" of the wood surface, thus decreasing the wood wettability and leading to poorer adhesion. (2) The solvent-repellant case hardening is due to the change of numerous chemical groups on the carbohydrates and lignin sites on the wood surface. (3) Heavy surface oxidation can take place, leading to changes in chemical groups and chemical rearrangements. At the same time, the cited authors stated that due to the degradation of the hemicellulose in the cell wall structure of the wood in high temperature heat treatment, adhesion was significantly reduced. 


\section{CONCLUSIONS}

1. The effect of heat treatment applied to pine and beech wood on the layer performances of water-based opaque paints were investigated. Heat treatment before application of the paint decreased the hardness, roughness, and adhesion strength of water-based opaque paints.

2. Depending on the increasing heat treatment temperature and time, decreases were found to be higher.

3. It was determined that the layer performance of water-based opaque paints was better at low temperature and time heat treatment applications.

\section{ACKNOWLEDGMENTS}

The authors thank KIMETSAN Company for their support.

\section{REFERENCES CITED}

Altun, S., and Esmer, M. (2017). "The effect of heat treatment on the surface roughness and varnish adhesion of wood," Journal of Polytechnic 20(1), 231-239.

ASTM D2240. (2010). "Standard test method for rubber property-durometer hardness," ASTM International, West Conshohocken, USA.

ASTM D3023-98. (2017). "Standard practice for determination of resistance of factoryapplied coatings on wood products to stains and reagents," ASTM International, West Conshohocken, USA.

ASTM D7787/D7787M. (2013). "Standard practice for selecting wood substrates for weathering evaluations of architectural coatings," ASTM International, West Conshohocken, USA.

ASTM D4541-17. (2017). "Standard test method for pull-off strength of coatings using portable adhesion testers," ASTM International, West Conshohocken, USA.

Aydemir, D., and Gündüz, G. (2009). "The effect of heat treatment on physical, chemical, mechanical and biological properties of wood," Journal of Bartın Faculty of Forestry 11(15), 61-70.

Bardage, S. L., and Bjurman, J. (1998). "Adhesion of waterborne paints to wood," Journal of Coatings Technology 70(878), 39-47.

Budakç1, M. (2006). "Design and production of a pneumatic adhesion testing device," Journal of Polytechnic 9(1), 53-58. DOI: 10.2339/2006.9.1.53-58

Budakç1, M., and Sönmez, A. (2010). "Determining adhesion strength of some wood varnishes on different wood surfaces," J. Fac. Eng. Arch. Gazi Univ 25(1), 11-118.

Budakçı, M., İlçe, A.C., Gürleyen, T., and Utar, M. (2013). "Determination of the surface roughness of heat-treated wood materials planed by the cutters of a horizontal milling machine," BioResources 8(3), 3189-3199. DOI: 10.15376/biores.8.3.3189-3199

Can, A. (2020). "Effects of heat treatment systems on the physical properties of coated scots pine (Pinus sylvestris L.) and poplar (Populus euramericana)," BioResources 15(2), 2708-2720. DOI: 10.15376/biores.15.2.2708-2720 
Can, A., Krystofiak, T., and Lis, B. (2021). "Shear and adhesion strength of open and closed system heat-treated wood samples," Maderas. Ciencia y Tecnología 23, 32, 110. DOI: $10.4067 / \mathrm{s} 0718-221 \times 2021000100432$

Cristea, M.V., Ried, B., and Blanchet, P. (2010). "Enhancing the performance of exterior waterborne coatings for wood by inorganic nanosized UV absorbers," Progress in Organic Coatings 69(4), 432-441. DOI: 10.1016/j.porgcoat.2010.08.006

Çakıcıer, N., Korkut, S., and Güler, F. D. (2011). "Effects of heating treatment on some of the physical properties of varnish layers applied on various wood species," African Journal of Biotechnology 10(9), 1578-1585.

Dagbro, O., Torniainen, P., Karlsson, O., and Morén, T. (2010). "Colour responses from wood, thermally modified in superheated steam and pressurized steam atmospheres," Wood Material Science and Engineering 5(3-4), 211-219. DOI: 10.1080/17480272.2010.520739

Dagbro, O. (2016). Studies on Industrial-Scale Thermal Modification of Wood, Ph.D. Dissertation, Luleå University of Technology, Luleå, Sweden.

Demirel, G. K., and Temiz, A. (2015). "Environmentally friendly wood modification methods," Journal of Selcuk-Technic 14(2), 1016-1032.

Dilik, T., Erdinler, S., Hazır, E., Koç, H., and Hiziroglu, S. (2015). “Adhesion strength of wood based composites coated with cellulosic and polyurethane paints," Advances in Materials Science and Engineering, 2015. DOI: 10.1155/2015/745675

Dunningham, E., and Sargent, R. (2015). Review of new and emerging international wood modification technologies (Project No: PNA350-1415), Forest and Wood Products Australia Limited, 978-1-925213-24-9, p. 56.

Gürleyen, L., Ayata, U., Esteves, B., and Çakıcıer, N. (2017). "Effects of heat treatment on the adhesion strength, pendulum hardness, surface roughness, color and glossiness of Scots pine laminated parquet with two different types of UV varnish application," Maderas. Ciencia y Tecnología 19(2), 213-224. DOI: 10.4067/S0718221X2017005000019

Hazir, E. and Koc, K.H. (2019). "Evaluation of wood surface coating performance using water based, solvent based and powder coating," Maderas. Ciencia y Tecnología 21(4), 467-480. DOI: 10.4067/S0718-221X2019005000404

Hill, C. A. (2006). Wood Modification: Chemical, Thermal and Other Processes, Vol. 5, John Wiley \& Sons. DOI: 10.1002/0470021748

Hill, C. A. (2009). "The potential for the use of modified wood products in the built environment," in: Proceedings of the $11^{\text {th }}$ International Conference on Nonconventional Materials and Technologies (NOCMAT 2009), 6-9 September 2009, Bath.

Kabakc1, A. (2018). The Hardness, Adhesion and Thermal Insulation Properties of Water-based Paint Applied as a Wood Layering Coating, Master's Thesis, Kastamonu University, Kastamonu, Turkey.

Karamanoğlu, M. (2012). The Restoration of Some Wood Materials Exposed to Outdoor Conditions by Bleaching Process, Master's Thesis, Düzce University, Düzce, Turkey.

Karamanoglu, M. (2020). Resistance Properties of Water-based Varnishes Modified with Nanoparticles against the Aging Effect of UV on Surface of Some Thermo-wood Materials, Ph.D. Dissertation, Kastamonu University, Kastamonu, Turkey.

Kaygin, B., and Akgun, E. (2008). "Comparison of conventional varnishes with nanolacke UV varnish with respect to hardness and adhesion durability," 
International Journal of Molecular Sciences 9(4), 476-485. DOI:

10.3390/ijms 9040476

Kazan, B. (2009). Based on Surface Water Varnish was Applied to the Heat Treatment Effect of, Master's Thesis, Dumlupinar University, Kütahya, Turkey.

Kesik, H. İ. (2009). The Layer Performance of Water Based Varnishes on Wood Preprocessed with Various Chemicals, Ph.D. Dissertation, Gazi University, Ankara, Turkey.

Kesik, H. İ., Korkut, S., Hiziroglu, S., and Sevik, H. (2014). “An evaluation of properties of four heat treated wood species," Industrial Crops and Products 60, 60-65. DOI: 10.1016/j.indcrop.2014.06.001

Kesik, H. İ., Vurdu, H., Çağatay, K., Özkan, O., and Öncel, M. (2015). "Hardness and adhesion characteristics of protective layer on oil heat treated scots pine wood," Kastamonu Univ., Journal of Forestry Faculty 15(2), 261-266.

Kesik, H. I., and Aky1ldı, M. H. (2015). "Effect of the heat treatment on the adhesion strength of water based wood varnishes," Wood Research 60(6), 987-994.

Kılıç, A., and Hafızoğlu, H. (2007). "Influences of weathering on chemical structure of wood and protection treatments," Süleyman Demirel University Journal of the Faculty of Forestry A (2), 175-183.

Kimetsan. (2021). "Water Based Paints," (http://www.kimetsan.com/contents/products/7/98), Accessed January 2021.

Korkut, S., and Budakçı, M. (2010). "The effects of high-temperature heat-treatment on physical properties and surface roughness of rowan (Sorbus aucuparia L.) wood," Wood Research 55(1), 67-78.

Korkut, D. S., Hiziroglu, S., and Aytin, A. (2013). "Effect of heat treatment on surface characteristics of wild cherry wood," BioResources 8(2), 1582-1590.

Miklecic, J., Jirouš-Rajković, V., Antonović, A., and Španić, N. (2011). "Discolouration of thermally modified wood during simulated indoor sunlight exposure,"

BioResources 6(1), 434-446. DOI: 10.15376/biores.6.1.434-446

Miklečić, J., Turkulin, H., and Jirouš-Rajković, V. (2017). "Weathering performance of surface of thermally modified wood finished with nanoparticles-modified waterborne polyacrylate coatings," Applied Surface Science 408, 103-109. DOI: 10.1016/j.apsusc.2017.03.011

Militz, H. (2002). "Heat treatment technologies in Europe: Scientific background and technological state of art," in: Proceedings of Conference-Enhancing the Durability of Lumber and Engineered Wood Products, Kissimmee, Orlando, Forest Product Society, Madison.

Pelit, H. (2014). The Effects of Densification and Heat Treatment to Finishing Process with Some Technological Properties of Eastern Beech and Scots Pine, Ph.D. Dissertation, Gazi University, Ankara, Turkey.

Pelit, H., Budakçı, M., Sönmez, A., and Burdurlu, E. (2015). "Surface roughness and brightness of scots pine (Pinus sylvestris) applied with water-based varnish after densification and heat treatment." Journal of Wood Science 61(6), 586-594. DOI: 10.1007/s10086-015-1506-7

Salca, E. A., and Hiziroglu, S. (2014). "Evaluation of hardness and surface quality of different wood species as function of heat treatment," Materials \& Design 62, 416423. DOI: 10.1016/j.matdes.2014.05.029 
Sönmez, A., Budakçı, M. and Yakın, M. (2004). "Effect of application methods on the hardness gloss and adhesion strength of waterborne varnish coating on the wooden surface," Journal of Polytechnic 7(3), 229-235.

TS 642 ISO 554. (1997). "Standard atmospheres for conditioning and/or testing; Specifications," Turkish Standards Institute, Ankara, TURKEY

TS 6956 EN ISO 4287/A1. (2013). "Geometrical Product Specifications (GPS) - Surface texture: Profile method - Terms, definitions and surface texture parameters Amendment 1: Peak count number (ISO 4287:1997/Amd 1:2009)," Turkish Standards Institute, Ankara, TURKEY

Ulay, G. and Budakçı, M. (2015). "Studies carried out in turkey regarding water-based varnishes used on wood surfaces," Düzce University Journal of Science and Technology 3(2), 470-480.

Ünsal, O. and Ayrılmış, N. (2005). "Variations in compression strength and surface roughness of heat-treated Turkish river red gum (Eucalyptus camaldulensis) wood," Journal of Wood Science 51(4), 405-409. DOI: 10.1007/s10086-004-0655-X

Article submitted: September 13, 2021; Peer review completed: November 20, 2021; Revised version received: November 25, 2021; Further revised version received and accepted: January 4, 2022; Published: January 11, 2022.

DOI: $10.15376 /$ biores.17.1.1494-1506 